\title{
Caribbean Literary History
}

\author{
Peter Hulme \\ Department of Literature, Film, and Theatre Studies, \\ University of Essex, Colchester, U.K. \\ phulme@essex.ac.uk
}

Caribbean Literature in Transition, 1800-1920: Volume 1. Evelyn O'Callaghan \& Tim Watson (eds.). Cambridge: Cambridge University Press, 2021. (Cloth US\$110.00)

Caribbean Literature in Transition, 1920-1970: Volume 2. Raphael Dalleo \& Curdella Forbes (eds.). Cambridge: Cambridge University Press, 2021. (Cloth US\$110.00)

Caribbean Literature in Transition, 1970-2020: Volume 3. Ronald Cummings \& Alison Donnell (eds.). Cambridge: Cambridge University Press, 2021. (Cloth US\$110.00)

In 1940, as the lines of communication between the Caribbean and Europe grew thinner and more stretched, the Jamaican W. Adolphe Roberts published the first history of the region as a whole (The Caribbean), sensing that what he called "our sea of destiny" connected the islands and rimlands to each other in ways ultimately more important than the Old World origins of many of their inhabitants and institutions. Roberts initiated a now illustrious synoptic historiographical tradition, one landmark of which is the six-volume UnEsco General History of the Caribbean (1997-2011). As always, literary history has lagged behind. In 1975 Roberto Márquez underlined the identity of the Caribbean "as an archipelago, as a specific world-historical setting and cultural-historical region of organically linked and dialectically interrelated societies," stating that "we desperately need ... nothing less than a comprehensive literary history of perhaps encyclopedic scope" (in Process of Unity in Caribbean Society [1983], pp. 96, 103). It took another 20 years for A History of Literature in the Caribbean (A. James Arnold [ed.], 3 vols., 1994-97) to appear, substantial if not quite encyclopedic. Now, of similar size and ambition, come the three volumes of Caribbean Literature in Transition. A team of six editors, led by Alison Don- 
nell, has done a tremendous job in coordinating these books. CUP has produced them immaculately and provided superb covers taken from paintings by Firelei Báez, LeRoy Clarke, and Christopher Cozier.

Immediately noticeable is a commendable absence of soul-searching as to the parameters of the area or the eligibility for inclusion. Instead there is a pleasing inclination to move, where appropriate, into Venezuela, Louisiana, and Central America, as well as North America, northern Europe, and Africa. In addition, serious attention is given not just to novels, poetry, and drama, but also to performance, text-networks, periodicals and newspapers, digital resources, testimonios, life-writing, creative nonfiction, talleres literarios, digital yards, and literary festivals and prizes. There are strong chapters in Volume 2 on publishing hubs (with a particularly innovative chapter on Canada). In other words, the volumes provide the kind of sociology of literature necessary to understand "the material circumstances that allowed Caribbean literature to thrive" (vol. 2, p. 8).

The volumes' conception of "literature" is as broad as their conception of "Caribbean." For the Arnold volumes, French, English, and Dutch Caribbean literatures, "to the extent that they can be called indigenous, are essentially twentieth-century phenomena" (vol. 1, p. xvi). As always in the Caribbean context, the word "indigenous" is problematic, but it is certainly notable that just a quarter of a century after these words were written a whole volume of essays can be dedicated to pre-1920 English (and to a lesser extent French) Caribbean literatures. As usual — though the Arnold volumes are an honorable exception-Dutch Caribbean literature is ignored here. The writers who most benefit from this expansion of focus are the nineteenth-century ones. Some of this writing has until recently been difficult to access and, as the editors of Volume 1 rightly note, "this opening up of the archive is one of the major transitions in contemporary Caribbean literary scholarship" (p. 5). Texts such as With Silent Tread, Rupert Gray, Adolphus, Hamel, the Obeah Man, Hiroona, Marly, and Obi; or Three-Finger'd Jack now take up their rightful places within the landscape of Caribbean literary history.

A few other highlights might be noted. The volumes are especially alert to connections between the written and the visual. George Robertson's paintings of Jamaica feature in two essays in Volume 1, which also includes a study of Joscelyn Gardner's Creole Portraits, while Volume 3 has an essay on the dialogic connections between literature and visual art. Volume 1 contains an essay on the notion of the diasporic archive that imaginatively rethinks the significance of Asian and Panamanian migrations for and in Anglophone Caribbean literature. This volume also includes rich study in two separate essays of Mary Seacole's Wonderful Adventures. Volume 2 has outstanding essays on "Poetry, 
Periodicals, and Newspaper Publishing" and on "Imaginaries of Citizenship and State." Life-writing is well served by two excellent essays in Volumes 2 and 3. Volume 3 includes fine essays on "Caribbean Urban Imaginaries" and "Creative Nonfiction." These titles and subjects perhaps give a sense of the scope and ambition of these volumes.

Underlining the significance of the term "transition" in the overall title, each volume is divided into four sections: "Literary and Generic Transitions," "Cultural and Political Transitions," "The Caribbean Region in Transition," and "Critical Transitions." The first three work perfectly adequately as containers for discussions of form, politics, and place, while the essays in "Critical Transitions" tend toward a more reflexive consideration of the relevance to Caribbean literary history of the newer frameworks offered by Black Atlantic studies, postcolonial studies, gender studies, queer studies, ecocriticism, and digital humanities. Broadly speaking, Volume 3 offers a series of snapshots of recent literary work; Volume 1 continues to extend the critical assessment of an understudied period; Volume 2, as its editors boldly announce, offers "a tangible critique of the literary history to date" (p. 2).

CU P's ambitious new collection of Literature in Transition series began with British literature and is now in the process of expanding to American, Irish, Asian American, African American, and Caribbean literatures. Welcome as these volumes are, Caribbean literature's place in the publishing pecking order is best gauged by a comparison with the African American Literature in Transition series, which is set to run to no fewer than 17 volumes, building on The Cambridge History of African American Literature (2011). These new series are clearly intended to offer something different from cup's Histories, Companions, and Introductions, the notion of transition implying new conceptualizations of literary historiography. With respect to British or U.S. literary history, it could certainly be claimed that the basic maps have been established and that the Handbooks and Companions have laid the historical groundwork: the "in transition" volumes can therefore build on these foundations by offering more comparative or left-field approaches. The press's website claims that each volume "surveys, interrogates and challenges prevailing assumptions of critical memory" and, as a result, "reinstates lost complexities and reanimates neglected debates." One possible problem here is that Caribbean literature has no equivalent CUP history, appearing only in The Cambridge History of African and Caribbean Literature (2004), whose very title suggests a view of the Caribbean as a neo-African appendage, and which dedicates fewer than 250 of its 900 pages to the region. The first volume of The Cambridge History of Latin American Literature (1996) covers some of the early writing about the Caribbean, but not with a specific Caribbean focus. With no foundations to build on, some 
of the essays in these three volumes read like basic literary history, sometimes focusing on a single author or even a single text—and are none the worse for that, given how much straightforward literary history of the area is still needed. Commendably, the authors are usually willing, given the opportunity, to offer purposefully disorientating perspectives in keeping with the objectives of the series.

Perhaps series titles should not be taken too literally: after all, the appearance of 72 high-quality essays on Caribbean literature produced by a prestigious university press ought to be unequivocally welcomed. In practice, many of the contributors do ignore the idea of "transition," although there is an occasional interesting focus on moments of transition such as 1865, 1898, or 1983, which begin to give a sense of shape and formation to each period. A generational perspective also does appear, fleetingly, and it is perhaps surprising that Anglophone literary historiography has not made more use of an approach commonplace in its Hispanic equivalent - and imaginatively used in recent years by David Scott in his essays in Small Axe to survey the postcolonial political scene in Jamaica.

In one respect, however, the generational point is particularly important. In its first phase Anglophone Caribbean literary history was largely formulated by its own postcolonial writers, who tended to be dismissive of their immediate predecessors: in her Twentieth-Century Caribbean Literature (2006) Donnell provided a meticulous analysis of this process of curation. It is always important for literary historians and archivists to challenge earlier forms of canonicity and propriety, adding further texts to thicken historical descriptions and to gain better awareness of the restraints and possibilities of prior momentsin other words to search for a fuller historicist understanding. So, in volume 2 writers who had become disconnected from the dominant critical discourses established towards the end of the twentieth century are reinserted into this broader canvas, among them W. Adolphe Roberts, John Hearne, Roger Mais, Garth St. Omer, Una Marson, Victor Reid, Andrew Salkey, and Elma Napier: "Forgotten Trailblazers", as one essay title calls them.

Quite properly the editors take every opportunity to underline the importance of archival work. There are at least three dimensions to this importance. Within existing archives - though these are probably in London, Aix, Seville, The Hague, or Copenhagen - are examples of writing from the first four centuries of Caribbean literary history which are still to enrich our picture of that early period. Then —and this time often within the Caribbean itself-are the papers of that "trailblazing" generation, usually in desperate need of location, preservation, and study. Where on earth, for example, are the papers of Herbert George de Lisser, one of the most significant Caribbean writers of the 
first half of the twentieth century, who belonged to a generation and a class who kept every scrap of paper? Finally, there are the materials belonging to the present generation of Caribbean writers. The last two dimensions are covered by Donnell's valuable Caribbean Literary Heritage project (https://www .caribbeanliteraryheritage.com/): as the subtitle has it, recovering the lost past and safeguarding the future.

One of the six UnEsco General History of the Caribbean volumes is dedicated to methodology and historiography. Here, in the books under review, rather than sustained attention to literary historiography, each volume has moments of reflexivity about the formation of a critical canon by the two previous generations. The continuing relevance of Sylvia Wynter's critical work is notable in this regard, but at least passing attention is also given to figures such as Ken Ramchand, Henry Swanzy, Kamau Brathwaite, and Edward Baugh, especially in a fine essay in Volume 2 on "Forging the Critical Canon." Perhaps even more recognition is due to pioneers of the regional approach: one thinks of Gabriel Coulthard, the centenary of whose birth falls this year.

Extensive as these three volumes are, it is impossible not to reflect on what they do not include. Perhaps inevitably, such reflection starts with the term "Caribbean." The editors are clear enough in their admission that the volumes' focus is on the Anglophone Caribbean: what used to be called, less ambiguously, the West Indies. Problems tend to arise when contributors simply refer to "Caribbean literature": it is often not immediately clear whether they are referring to the region as a whole or simply to the Anglophone part. So, despite some refreshing additional essays on the Hispanophone and Francophone Caribbean, the approach here is never fully regional.

Then, what one might have thought to be the nonissue of when Caribbean

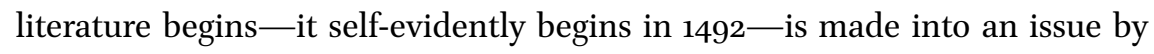
the puzzling decision to start these volumes in 1800 . Periodization is always up for discussion and the breaks at 1800, 1920, and 1970 in themselves make as good sense as any, but to designate 1800 to 1920 as "early" begs the question of what term one might then use for 1492 to 1800 . Even the recent landmark volume Literary Histories of the Early Anglophone Caribbean (2018) treats "early" as the period from 1492 to emancipation; and, once the category of "literature" has been broadened, the pre-18oo period in the Caribbean is richly carpeted with travel accounts and ethnographic descriptions which have, even beyond their own merits, provided the material for later novelists such as Alejo Carpentier, Antonio Benítez Rojo, and Barry Unsworth. Here, the 1800 starting date disappointingly excludes such towering Caribbean figures as Ramón Pané, Gonzalo Fernández de Oviedo, and Jean-François Du Tertre, while Christopher Columbus and Jean-Baptiste Labat appear only because they are mentioned 
by Edward Long, James Anthony Froude, and Maria Nugent, who appear in the first volume's opening chapter, ironically entitled "Conquest Narratives," which, despite its purported attention to the region's indigenous population, manages to misspell "Kalinago" throughout (though it should be pointed out that this reader spotted fewer than ten typos in the volumes' nearly 1400 pages). Even given the Anglophone focus, the 1800 starting point eliminates from consideration a whole swathe of writers who established many of the templates for trying to understand the region, the most important probably being Walter Ralegh.

In the end, both of those efforts-Arnold's and Donnell's-(significant and praiseworthy as they are) fall short of offering the kind of encyclopedic synopsis of the kind that Roberto Márquez had in mind in 1975. Perhaps Caribbean literary historiography — still a young discipline — has not yet produced scholars of the stature of Gordon Lewis and Franklin Knight who can range with authority across the whole Caribbean, although these three volumes under review do feature encouraging examples of younger scholars with the requisite linguistic skills and the evident desire to look at the region as a whole. As the general editor puts it, there are here a number of essays that "signal the transition to a more ambitiously transversal, transnational Caribbean literary studies in the making" (vol. 3, p. 408). The most exciting moments for this reader were the occasional juxtapositions: Baron de Vastey with Robert Wedderburn, Warner Arundell with Sab, John Jacob Thomas with Salomé Henríquez de Ureña, Eric Williams with Fernando Ortiz, Claude McKay with Aimé Césaire, Kei Miller with Rita Indiana Hernández. Putting these pairs of writers into the same frame begins to suggest what a fuller Caribbean literary history might eventually have to offer. Perhaps in 2041 CUP will publish the six-volume Cambridge History of Caribbean Literature, 1492-2040, finally to do justice to what Derek Walcott called in his Nobel lecture "one literature in several imperial languages." 